\title{
On the Depth of Capture of Bigeye Tuna by Further Improved Vertical Long-line in the Tropical Pacific*1
}

\author{
Shoji SAITO ${ }^{* 2}$ \\ (Received May 00, 1975)
}

\begin{abstract}
In January to February 1974, a total of 12 daytime sets of the further improved vertical long-line gear was made in the North Equatorial Current areas. Compared with the improved vertical long-line gear that had been used previously, there appeared to be no difference in the frequency of branch line fouling, and the time required to retrieve the gear was reduced by $11 \%$ per unit (one basket). Compared with the commercial long-line gear fished at the same time, there was no significant difference in the catch rates, but a highly significant difference was detected in the species composition of the catch. According to the $95 \%$ confidence intervals for ratio of occurrence of the species, this vertical long-line catch was significantly higher than the commercial long-line catch, in bigeye tuna, Tunnus obesus, only. It is indicated that this gear is effective in catching fish. The depth layer in which bigeye tuna were captured was below or near the vicinity of the bottom of the thermocline, where the temperature ranged from $11^{\circ} \mathrm{C}$ to $15^{\circ} \mathrm{C}$.
\end{abstract}

The bigeye tuna is one of the important species of tunas. Generally, the swimming depth of this species has been known to be deeper than others (MURPHY et al. ${ }^{11}$, WATA$\mathrm{NABE}_{9}{ }^{2)}$ and $\mathrm{WATANABE}^{3}$ ). Furthermore, in studies using fish finders, the records indicate that bigeye tuna were distributed at the $300 \mathrm{~m}-400 \mathrm{~m}$ depths (SHrBATA et al. ${ }^{4}$, and YUKINAWA et $\left.a l^{5}\right)$ ). In the fishing experiments with the vertical long-line gear in the area west of Fiji Islands, SAITo et al.$^{6)}$ reported that the capture of bigeye tuna was made even at the great depth of $380 \mathrm{~m}$.

However, few studies on the swimming depth of bigeye tuna have been reported in the past, and almost all of this imformation are due to studies of catches made on long-line gear wherein its is difficult to determine the actual depths of the various hooks and where the vertical depth distribution of the hooks is not wide. Therefore, the improved vertical long-line gear $^{6 /}$ which removed the deficiencies of the long-line gear, was further improved to catch fish more efficiently. The fishing experiments with the further improved vertical long-line gear were conducted in the fishing ground of bigeye tuna in the North Equatorial Current region. In order to examine the relative efficiency of this vertical long-line gear, comparisons were made with the commercial long-line gear fished at the same time.

\section{Method and gear}

Further improved vertical long-line gear The further improved vertical long-line gear

*1 Reported at Annual Meeting of Japanese Tuna Conference in February 1975.

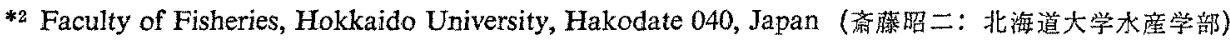


is an improved version of the improved vertical long-line gear used previously. ${ }^{3)}$ The construction details, the components of the branch line having an important part in the efficiency of the fishing gear, and the branch line attachments of the improved gear, are shown in Table 1 and Fig. 1. On the construction of the branch line, the length of the fiber material was cut so that it would be able to support the weight of the metal part in water and have

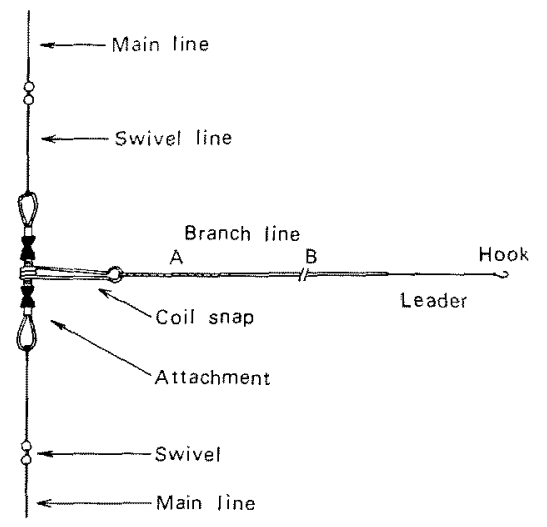

Fig. 1. Schematic diagram of further improved vertical long-line gear extra buoyancy. The branch line material was a specially treated polypropylene, a synthetic fiber having a low specific gravity. In order to permit easy movement by even a weak current, the branch line was made very light. The torque that develops in the main line during the retrieval of the gear is not transmitted to the branch line by the action of the branch line attachment; therefore, the winding of the branch line is prevented. The branch line attachment does not hamper the operation of the long-line hauler and allows continuous hauling of the gear.

Table 1. Specification of further improved vertical long-line gear

\begin{tabular}{|c|c|c|c|c|}
\hline Name of part & Material & $\begin{array}{l}\text { Weight } \\
\text { in water } \\
(\mathrm{g})\end{array}$ & Length & Number \\
\hline Branch line $(\mathrm{A})^{*}$ & $\begin{array}{l}\text { Polypropylene \& Cremona mixed } \\
(5.7 \mathrm{~mm} \phi)\end{array}$ & 0.9 & $4.5 \mathrm{~m}$ & 5 \\
\hline$-(\mathrm{B})^{*}$ & $\begin{array}{l}\text { Specially treated polypropylene } \\
(6.5 \mathrm{~mm} \phi)\end{array}$ & -37.5 & $12.0 \mathrm{~m}$ & 5 \\
\hline Leader & Steel wire $(30 \#, 3+9)$ & 9.6 & $1.46 \mathrm{~m}$ & 5 \\
\hline $\begin{array}{l}\text { Hook } \\
\text { (with swivel) }\end{array}$ & Steel & 12.5 & $103 \mathrm{~mm}$ & 5 \\
\hline Float & Synthetic resin ball & & $\phi 30 \mathrm{~cm}$ & 1 \\
\hline Float line & Cremona $(20 \mathrm{~S}, 55 \times 3 \times 3)$ & & $108 \mathrm{~m}$ & 1 \\
\hline Main line & Cremona $(20 \mathrm{~S}, 55 \times 3 \times 3)$ & & $40 \mathrm{~m}$ & 4 \\
\hline Swivel line & Cremona $(20 \mathrm{~S}, 35 \times 3 \times 3)$ & & $83.5 \mathrm{~cm}$ & 10 \\
\hline Branch line attachment & $\begin{array}{l}\text { Stainless steel wire, coil spring \& } \\
\text { coil snap }\end{array}$ & & $20 \mathrm{~cm}$ & 5 \\
\hline Weight line & Cremona $(20 \mathrm{~S}, 55 \times 3 \times 3)$ & & $80 \mathrm{~m}$ & 1 \\
\hline Weight & Steel $(1.0 \mathrm{~kg})$ & & & 1 \\
\hline
\end{tabular}

Number: Number used for 1 basket $\phi$ : Diameter

* : $A+B=16.5 \mathrm{~m}$ (Overall length of branch line)

Form of branch line in water The relative position between the main line and the hook which is an important factor in catching fish, is determined by the form of the branch line in the water. It is believed that the form of the branch line has an important effect on the 
fishing efficiency of the vertical long-line gear. Here, the design of the branch line was determined experimentally by observations of the form of the branch line in the water. The experiment was conducted as follows: In the beginning, the fiber of the branch line was permeated with seawater which allowed the branch line to sink to a depth of $300 \mathrm{~m}$. A calm sea condition was selected to conduct the experiments. The branch line which was baited with horse mackerel (weight in water, $3 \mathrm{~g}$ ) was attached to the line (diameter, $6.0 \mathrm{~mm}$; length, $50 \mathrm{~m}$ ) which was weighted at the bottom and suspended by a float on the sea surface. The gear was allowed to drift with the current. Then, the depth of the branch line attachment was changed, after the form of the branch line was observed. The branch line was attached on marks at $10 \mathrm{~m}$ intervals. Photographs were made by using the underwater camera (Nippon Kogaku K. K., Nikonos II, UW-Nikkor, f=28 mm, 1: 3.5 Lens) at the same time. The results obtained are shown in Fig. 2.

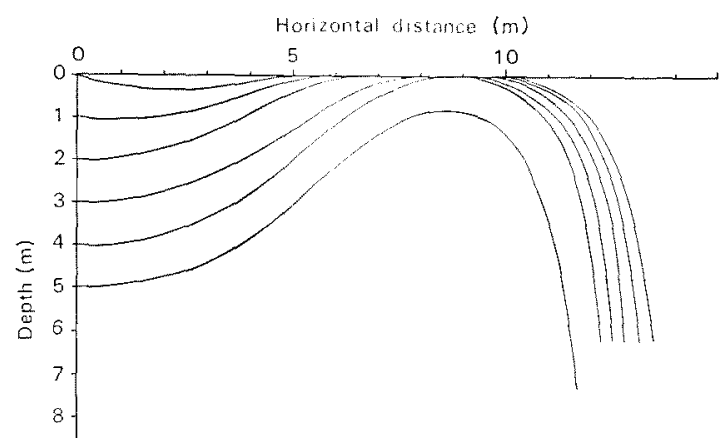

Fig. 2. Results of experiments on the form of the branch line in water Relative rate of current: $9.5 \mathrm{~cm} / \mathrm{sec}$.

In a current of $9.5 \mathrm{~cm} / \mathrm{sec}$, the highest point of the form of the branch line is $6.5 \mathrm{~m}$ from the end of the fiber part, and its relative position is $4.2 \mathrm{~m}$ shallower than the attaching point of the branch line, with $8.6 \mathrm{~m}$ horizontal distance. And the relative position of the hook which is attached at the extreme end of the wire leader is $2.3 \mathrm{~m}$ deeper than the attaching point of branch line, with $11.7 \mathrm{~m}$ horizontal distance.

The current (relative rate) was calculated by measuring the time required for the target $\left(2 \times 3 \times 1 \mathrm{~cm}^{3}\right)$, made from foam polystyrol, to drift the distance of $10 \mathrm{~m}$. The target was weighted with a metallic weight so that it did not project above the sea surface. The track of the target drift was laid along a marked polypropylene rope that was allowed to stream out on the surface from the float mentioned above.

Method From 25 January to 9 February 1974, the fishing experiments were conducted at lat. $10^{\circ}-15^{\circ} \mathrm{N}$, long. $172^{\circ}-175^{\circ} \mathrm{W}$. Each fishing set consisted of $19-20$ units of the further improved vertical long-line gear. Twelve daylight sets were made as shown in Fig. 3. At the same time, the commercial long-line gear was also fished. The fishing results 


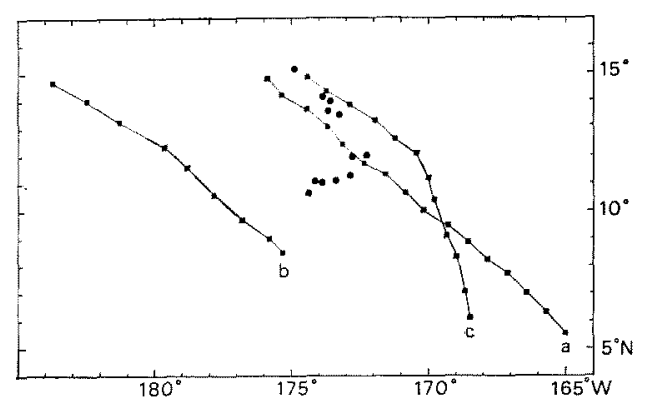

Fig. 3. Locations of fishing experiments and hydrographic stations (by bathythermograph)

-: Fishing experiments

(a): Cruise of research vessel "Aomori Maru", 9-13 January 1969

(b): Cruise of research vessel "Tsurugi Maru", 27-31 January 1970

(c): Cruise of research vessel "Tsurugi Maru", 20-26 January 1971

of 20 units of the commercial long-line gear that did not differ greatly in setting position and soaking time were compared with the vertical long-line results.

\section{Results and considerations}

Operation of vertical long-line gear The operations of the further improved vertical long-line gear and the commercial long-line gear are summarized in Table 2. The time required to retrieve one unit of the vertical long-line gear averaged 3.15 minutes. In spite of the overall length of one unit (from float to weight) of this gear, which is $38 \mathrm{~m}$ longer than that of the improved vertical long-line gear, the time was reduced to $0.39 \mathrm{~min}$ (about $11 \%$ ) per unit. On the other hand, the time required to retrieve one unit of the commercial long-line gear (six-hook gear, float line, $22 \mathrm{~m}$; main line, $350 \mathrm{~m}=50 \mathrm{~m} \times 7$; branch line, $22 \mathrm{~m}$ ) averaged $2.55 \mathrm{~min}$. The vertical long-line gear was set after the completion of setting of the commercial long-line gear, and the hauling of it was started with the unit that was set last. Therefore, the soaking time of the vertical long-line gear averaged

Table 2. Results of operation of further improved vertical long-line gear and commercial long-line gear

\begin{tabular}{lll}
\hline \hline \multicolumn{1}{c}{ Item } & \multicolumn{1}{c}{ Vertical long-line } & \multicolumn{1}{c}{ Long-line* } \\
\hline Number of basket used & $19-20$ baskets/day & 20 baskets/day \\
Time started to set & $0810-0906$ & $0751-0849$ \\
Time finished to set & $0828-0922$ & $0807-0905$ \\
Ave. time taken for setting & $0.78 \mathrm{~min} /$ basket & $0.90 \mathrm{~min} /$ basket \\
Time started to haul & $1213-1352$ & $1317-1452$ \\
Time finished to haul & $1314-1449$ & $1406-1541$ \\
Ave. time taken for hauling & $3.15 \mathrm{~min} /$ basket & $2.55 \mathrm{~min} /$ basket \\
Ave. soaking time & 0446 & 0601 \\
\hline
\end{tabular}

*: Six-hook gear (Main line: $350 \mathrm{~m}=50 \mathrm{~m} \times 7$, float line: $22.0 \mathrm{~m}$ ) 
4 hours 46 minutes, and is shorter than the 6 hours 1 minute of that of the commercial long-line gear.

The hook depths of the vertical long-line gear and the commercial long-line gear were determined by the use of the automatic depth meters as reported by SAITo et al. ${ }^{7}$, and SAIto. ${ }^{8)}$ The results are shown in Table 3. From this table, it can be seen that the actual depth of Hook-5 of the vertical long-line gear was $245 \mathrm{~m}(\bar{x}=244.9$, s. d. $=17.56, n=27)$. If it is assumed that an inclination of the line by the resultant influence of current is straight, the calculated angle of inclination averaged $28^{\circ}$. The actual hook depths reached about $88 \%$ of the calculated depths. On the other hand, the actual depth of the deep hook (Hook-3) of the commercial long-line gear is $140 \mathrm{~m}(\overline{\mathrm{x}}=128.3$, s. d. $=11.03, \mathrm{n}=42$, provided that the automatic depth meter was attached to the branch line at intervals of $12 \mathrm{~m}$ from the hook), and is approximately equivalent to the depth of Hook-2 of the vertical long-line gear.

Table 3. Catches by further improved verticali long-line gear and commercial long-line gear

\begin{tabular}{|c|c|c|c|c|c|c|c|c|c|c|c|}
\hline & & \multicolumn{6}{|c|}{ Vertical long-line } & \multicolumn{4}{|c|}{ Long-line } \\
\hline \multicolumn{2}{|c|}{ Hook position } & 1 & 2 & 3 & 4 & 5 & Total & 1 & 2 & 3 & Total \\
\hline \multicolumn{2}{|c|}{ Hook depth $(\mathrm{m})^{* 1}$} & 96 & 133 & 170 & 207 & 245 & & 82 & 116 & 140 & \\
\hline \multicolumn{2}{|c|}{ Number of hooks } & 230 & 230 & 230 & 230 & 230 & 1150 & 480 & 480 & 480 & 1440 \\
\hline \multicolumn{2}{|c|}{ Catch rate $(\%)^{* 2}$} & 0.00 & 0.43 & 1.30 & 1.74 & 1.74 & 1.04 & 0.00 & 0.21 & 0.21 & 0.14 \\
\hline \multirow{5}{*}{$\frac{\tilde{g}}{\tilde{g}}$} & Bigeye tuna & & 1 & 3 & 4 & 4 & 12 & & 1 & 1 & 2 \\
\hline & Yellowfin tuna & 1 & & & & & 1 & 1 & & 3 & 4 \\
\hline & Albacore & & & & & & 0 & & & 2 & 2 \\
\hline & Blue marlin & 1 & & & & & 1 & 1 & & & 1 \\
\hline & Shortbill spearfish & 2 & & 1 & & & 3 & 3 & 3 & & 6 \\
\hline \multicolumn{2}{|c|}{ Total number } & 4 & 1 & 4 & 4 & 4 & 17 & 5 & 4 & 6 & 15 \\
\hline \multicolumn{2}{|c|}{ Catch rate $(\%)$} & 1.74 & 0.43 & 1.74 & 1.74 & 1.74 & 1.48 & 1.04 & 0.83 & 1.25 & 1.04 \\
\hline
\end{tabular}

*1: Hook depth measured by the automatic depth meter

*2: Catch rates of bigeye tuna

The depth of capture of bigeye tuna The results of fishing by the further improved vertical long-line gear are shown in Table 3. The bigeye tuna catch amounted to $70 \%$ of the total catch, and the catch rate (number of fish per 100 hooks fished), was $1.48 \%$. The results of the fishing by the long-line gear are also shown in Table 3. The total catch rate was $1.04 \%$, and was lower than that of the vertical long-line gear. And, in contrast to the catches of the vertical long-line, the bigeye tuna catch was small, and the catches of marlins and other species of tunas (albacore and yellowfin tuna) were comparatively good.

Studies on the fishing duration, which may be an important problem in the consideration of the depth of capture, have been reported as follows: From experiments with the automatic depth meter, SAITO et al. ${ }^{7}$, KANAGAWA PREFECTURAL FISHERIES EXPERIMENTAL STATION, ${ }^{9)}$ and SAITO ${ }^{8 /}$ reported that albacore are caught after the gear settles into fishing position (i. e., not during sinking or retrieval). Therefore, the actual hook depth at which a fish is taken can be recognized to be the depth of capture. 
From the results of the fishing experiments reported on here, the author examined the catch rates and the species composition obtained by the two types of gear that fished at different depths. Comparisons of the variances and means of the total catch rates were made between the vertical long-line gear and the commercial long-line gear. The results obtained are as shown in Table 4. There were no significant differences between them. But, the results of the chi-square test showed a highly significant difference between the species compositions of both catches (Table 5). The $95 \%$ confidence intervals of the ratio of occurrence of the species are shown in Fig. 4. According to the results, for the tunas (albacore and yellowfin tuna) and the marlins, there was no significant difference between both gears, while for the bigeye tuna, the vertical long-line gear was significantly higher than the long-line gear. Therefore, it is indicated that the bigeye tuna catch on the vertical long-line gear was better than that of the longline gear. It is believed that the deep swimming bigeye tuna was effectively taken by ${ }_{\star}$ the vertical long-line gear because it fished at depths greater than the long-line gear.

The line foulings of branch lines (i. e., tangling, winding, etc.) that may have an effect on the catch rate of the vertical long-line gear were examined as follows: The frequency of branch line foulings of the further improved vertical long-line gear is given in Table 6 . In comparison with the improved vertical long-line gear reported previously, there appears to

Table 4. Comparison of variances and means, using values of the logarithmic transformation of catch per 100 hooks (catch rate)

\begin{tabular}{|c|c|c|c|}
\hline \multirow[b]{2}{*}{$\log (X+1)$} & \multicolumn{3}{|c|}{ Catch } \\
\hline & \multicolumn{2}{|c|}{$\begin{array}{l}\text { Vertical long-line }{ }^{* 1} \\
\mathbf{n}\end{array}$} & $\underset{\mathbf{n}}{\text { Long-line }}{ }^{* 2}$ \\
\hline $0.0-0.1$ & \multicolumn{2}{|c|}{2} & 3 \\
\hline \multicolumn{4}{|l|}{$0.1-0.2$} \\
\hline $0.2-0.3$ & & & 4 \\
\hline $0.3-0.4$ & \multicolumn{2}{|c|}{5} & \\
\hline $0.4-0.5$ & \multicolumn{2}{|c|}{3} & 4 \\
\hline $0.5-0.6$ & & & 1 \\
\hline $0.6-0.7$ & \multicolumn{2}{|c|}{2} & \\
\hline \multicolumn{4}{|l|}{$0.7-0.8$} \\
\hline \multicolumn{4}{|l|}{$0.8-0.9$} \\
\hline \multicolumn{4}{|l|}{$0.9-1.0$} \\
\hline Total & \multicolumn{2}{|c|}{12} & 12 \\
\hline Mean & \multicolumn{2}{|c|}{0.353} & 0.275 \\
\hline Variance & \multicolumn{2}{|c|}{0.0404} & 0.0355 \\
\hline Test of & $\mathbf{F}$ & d. f. & Pr. \\
\hline variance & 1.138 & 11,11 & $0.25-0.50$ \\
\hline \multirow{2}{*}{$\begin{array}{l}\text { Test of } \\
\text { mean }\end{array}$} & $t$ & d.f. & Pr. \\
\hline & 0.981 & 22 & $0.20<$ \\
\hline
\end{tabular}

$\mathrm{X}$ : Number of fish per 100 hooks fished

$\mathrm{n}$ : Number of fishing operation

*1: Average 96 hooks per one operation

*2: Average 120 hooks per one operation 
Table 5. Chi-square test of species composition by the fishing gears

\begin{tabular}{lcccc}
\hline \hline \multirow{2}{*}{ Species } & & \multicolumn{2}{c}{ Catch } & \\
\cline { 2 - 5 } & Vertical long-line & Long-line & Total \\
\hline Bigeye tuna & 12 & 2 & 14 \\
Tunas & 1 & 6 & 7 \\
Marlins & 4 & 7 & 11 \\
Total & 17 & 15 & 32 \\
\hline$\chi^{2}=11.73$ & d. f.: 2 & Pr. $<0.005$ & & \\
\hline
\end{tabular}

Tunas: Albacore, Yellowfin tuna. Marlins: Blue marlin, Shortbill spearfish

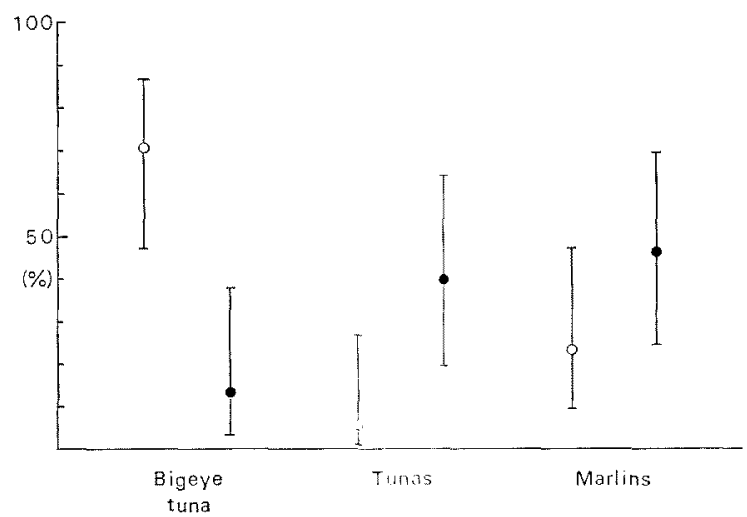

Fig. 4. The $95 \%$ confidence intervals for ratio of occurrence of the species by the two types of gear $O:$ Vertical long-line catch. : Long-line catch

be no great difference in the rate of fouling of Hook-1, Hook-2 and Hook-3, but the difference is somewhat greater for Hook-4 and Hook-5. It is believed that this was caused by the insufficient twist of the new weight lines. However, it is known that virtually all of the branch line fouling is caused by the twist of the line that develops during the retrieval of the gear, when the torque of the main line causes the branch lines to wind around the main line. There is no effect on the fishing efficiency of the gear because the characteristic winding of the branch line differs from that of the tangling of the branch line. Therefore, in comparison with the improved vertical long-line gear, ${ }^{b /}$ it is considered that there is no difference in the catch rates due to branch line foulings.

Table 6. Frequency of branch lines fouling of further improved vertical long-line gear

\begin{tabular}{ccccc}
\hline Hook position & $\begin{array}{c}\text { Number of } \\
\text { branch line } \\
\text { tangled }\end{array}$ & $\begin{array}{c}\text { Number of } \\
\text { branch line } \\
\text { winded }\end{array}$ & Total & $\begin{array}{c}\text { Rate of } \\
\text { fouling (\%) }\end{array}$ \\
\hline 1 & 15 & 14 & 29 & 12.6 \\
2 & 3 & 15 & 18 & 7.8 \\
3 & 2 & 22 & $2 A$ & 10.4 \\
4 & 13 & 30 & 43 & 18.7 \\
5 & 18 & 41 & 59 & 25.6 \\
Total & 51 & 122 & 173 & 15.0 \\
\hline
\end{tabular}


The depth of capture of bigeye tuna and the thermocline TsuchIYA $^{10)}$ pointed out that the position of the North Equatorial Countercurrent is on the average from lat. $3^{\circ} \mathrm{N}$ to $8^{\circ} \mathrm{N}$. in the western Pacific. And. YamanaKa ${ }^{11)}$ reported that from January to March the North Equatorial Countercurrent is located at approximately $3.5^{\circ} \mathrm{N}-7.5^{\circ} \mathrm{N}$ in the western Pacific west of long. $180^{\circ}$, and that its northern and southern boundaries indicate meandering in all seasons. Therefore, it is evident that the experimental stations were located in the North Equatorial Countercurrent area
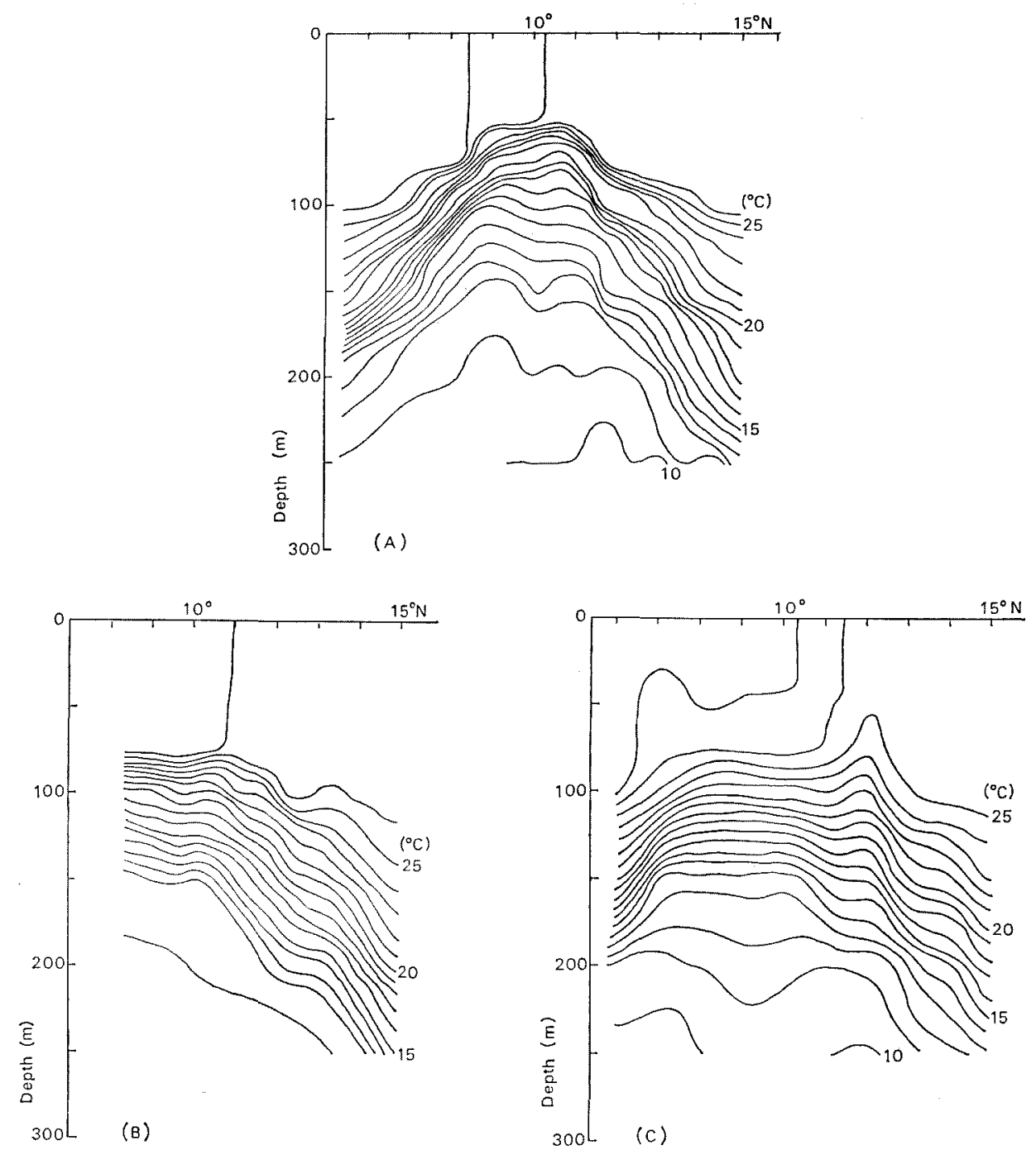

Fig. 5. Vertical sections of temperature.

(A): Vertical section along (a) shown in Fig. 3

(B): Vertical section along (b) shown in Fig. 3

(C): Vertical section along (c) shown in Fig. 3 
The vertical distributions of temperature of this area from recent observations are represented in Fig. 5 (A, B, C). According to Fig. 5 (A, B, C) respectively, the $11^{\circ} \mathrm{C}$ to $26^{\circ} \mathrm{C}$ isotherms dipped downward from lat. $10^{\circ} \mathrm{N}$ to $15^{\circ} \mathrm{N}$, i. e., from the adjacent northern boundary of the North Equatorial Countercurrent to the North Equatorial Current area. This tendency is in agreement with that reported by TsuCHIYA ${ }^{10)}$, MONTOGOMERY et al ${ }^{15)}$, and YAMANAKA, ${ }^{18)}$ respectively.

To examine the vertical distribution of bigeye tuna, the depth of capture was plotted along latitude and the isotherms shown in Fig. 5 (Fig. 6). The depth range of Hook-1 through Hook- 5 of the vertical long-line gear are also indicated in this figure. According to Fig. 6 , the $11^{\circ} \mathrm{C}$ to $15^{\circ} \mathrm{C}$ isotherms are widely spaced and scattered in the southern latitudes, but are dense and not as scattered in the northern latitudes. On the other hand, in spite of the large number of hooks that were fished in the depths shallower than the $15^{\circ} \mathrm{C}$ isotherm, bigeye tuna were not taken in these depths but were taken in depths occupied only by the $11^{\circ} \mathrm{C}$ to $15^{\circ} \mathrm{C}$ isotherms.

The vertical distributions of temperature at lat. $11^{\circ} \mathrm{N}$ and $14^{\circ} \mathrm{N}$ where bigeye tuna were relatively abundant, as indicated in Fig. 6, are shown in Fig. 7. According to Fig. 7, at lat. $11^{\circ} \mathrm{N}$, a steep thermocline was found between from $60 \mathrm{~m}$ or $80 \mathrm{~m}$ to $150 \mathrm{~m}$, and the bigeye tuna catches were relatively large at $170 \mathrm{~m}$ (Hook-3) and $207 \mathrm{~m}$ (Hook-4) depths. Therefore, it is apparent that the catches were made in depths near or below the vicinity of

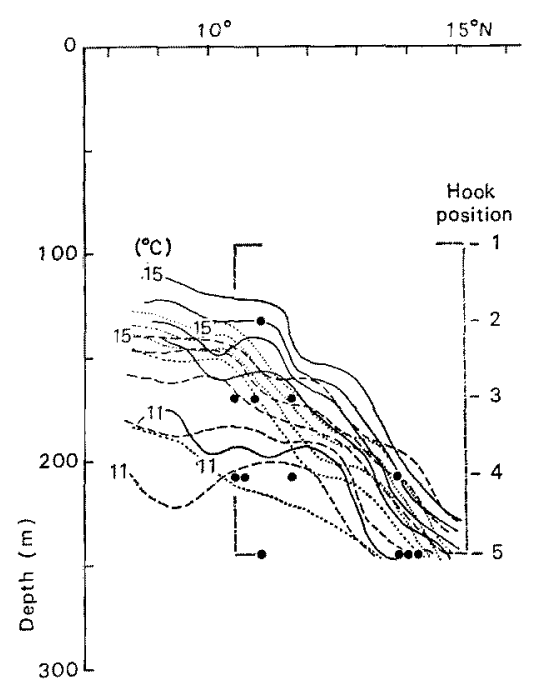

Fig. 6. Relation between depths of capture of bigeye tuna and vertical sections of temperature ....-: Range of hook fished. : Depth of capture of bigeye tuna

- Isotherms shown in Fig. 5 (A)

-..-: Isotherms shown in Fig. 5 (B)

-.--: Isotherms shown in Fig. 5 (C) 

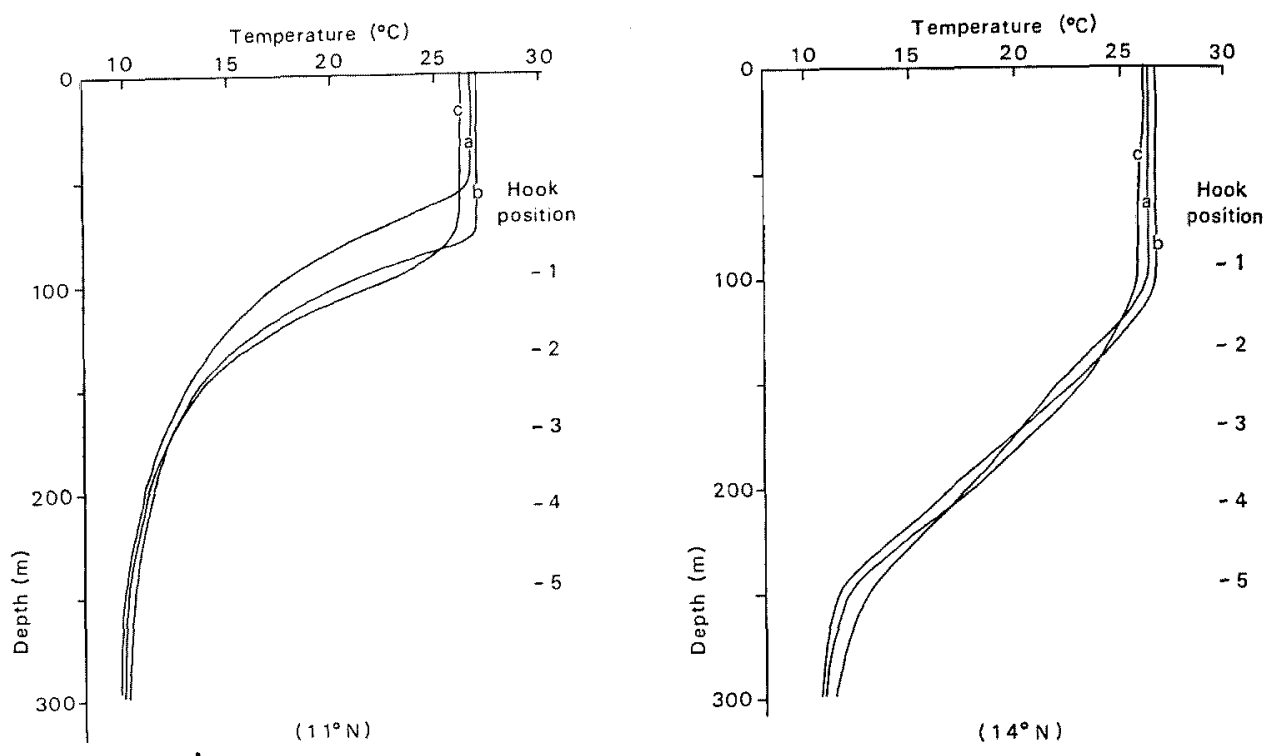

Fig. 7. Relation between thermoclines and depths of hooks, at $11^{\circ} \mathrm{N}$ and $14^{\circ} \mathrm{N}$

a: Vertical distribution of temperature observed at (a) shown in Fig. 3

b: Vertical distribution of temperature observed at (b) shown in Fig. 3

c: Vertical distribution of temperature observed at (c) shown in Fig. 3

the bottom of the thermocline. On the other hand, at lat. $14^{\circ} \mathrm{N}$, the thermocline is not as well developed in the greater depths of $110 \mathrm{~m}-260 \mathrm{~m}$ and the catches were relatively large at $245 \mathrm{~m}$ (Hook-5). Accordingly, it is apparent that the catches were made at the vicinity of the bottom of the thermocline. Consequently, in this region, it is indicated that the depth of capture of bigeye tuna is along the vicinity of the bottom or below the thermocline. These results generally agree with the results reported by KAWAI, ${ }^{17)}$ and SUDA et al. ${ }^{18)}$ Now, in considering the optimum water temperature, the temperature in the middle of the thermocline at lat. $11^{\circ} \mathrm{N}$ was $19.5^{\circ} \mathrm{C}$, and that at lat. $14^{\circ} \mathrm{N}$ was $19.0^{\circ} \mathrm{C}$. This temperature is close to the $20^{\circ} \mathrm{C}$ (approximate) reported by MURPHY et al..$^{11}$, WoOsTer et al. ${ }^{19}$, CROMWELL, ${ }^{20)}$ BRANDHORST, ${ }^{21)}$ and YAMANAKA et $a l .{ }^{22)}$ in the past. But, as mentioned above, the temperatures at the depth of capture of bigeye tuna were less than $15^{\circ} \mathrm{C}$, and there were great differences from the optimum temperatures $\left(17.5^{\circ}-22.0^{\circ} \mathrm{C}\right)$ reported by UDA. ${ }^{23}$ )

\section{Acknowledgements}

I would like to express my appreciation for the valuable guidance received in this study from Prof. Kenichiro KYUSHIN of the Faculty of Fisheries, Hokkaido University. The author also wishes to express his thanks to President M. KonNo, Managing director T. Konno and the crew members of fishing vessel No. 38 Ekyu Maru of Konno Suisan Co., Ltd. for their cooperation in the conduct of my experiments. Moreover, I wish to thank 
Mr. Howard Yoshida, National Marine Fisheries Service, Honolulu Laboratory, who kindly revised my English manuscript.

\section{References}

1) G. I. MurPhy and R. S. Shomura: Spe. Sci. Rep. Fish., 137, 1-42 (1955).

2) H. Watanabe: Rep. Kanagawa Pref. Fish. Exp. Stat., 4, 1-11 (1961).

3) H. Watanabe: Rep. Nankai Reg. Fish. Res. Lab., 7, 72-81 (1958).

4) K. Shibata and N. Nishimura: Bull. Fac. Fish. Nagasaki Univ., 28, 43-67 (1969).

5) M. Yukinawa, H. Yamanaka and J. Morita: Data Jap. Tuna Conf., 46-9, 21-31 (1972).

6) S. SAIro and S. SASAKI: This Bull., 40, 643-649 (1974).

7) S. SArto, K. Ishu and K. Yoneta: ibid., 36, 578-584 (1970).

8) S. SaIto: Mem. Fac. Fish. Hokkaido Univ., 21, 107-184 (1973).

9) Kanagawa Pref. fish. exp. Stat.: Rep. Kanagawa Pref. Fish. Exp. Stat., 156, 1-48 (1970).

10) M. Tsuchiya: Oceanogr. Mag., 13, 1-30 (1961).

11) H. Yamanaka: Bull. Far Seas Fish. Res. Lab., 9, 19-43 (1973).

12) Fisheries AGenCY: Results Fish. Oceanogr. Obs., 1464-1465 (1972).

13) Fisheries AGeNCY: ibid., 1666-1667 (1973).

14) Fisheries AGENCY: ibid., 821-822 (1974).

15) R. B. Montogomery and E. D. Stroup: The Johns Hopkins Oceanogr. Stud, 1, 1-68 (1952).

16) H. Yamanaka: Bull. Jap. Soci. Fish. Oceanogr., 15, 9-14 (1969).

17) H. KawaI: Proc. Jap. Tuna Conf., 245-247 (1967).

18) A. Suda, S. Kume and T. Shrohama: Bull. Far Seas Fish. Res. Lab., 1, 99-114 (1969).

19) W. S. Wooster and T. Cromwell: Bull. Scripps Inst. Oceanogr. Univ. Calif, 7, 1969-281 (1958).

20) T. CromWell: IATTC Bull, 111, 135-164 (1958).

21) W. Brandhorst: Jour. Conseil, 24, 16-31 (1958).

22) H. Yamanaka, N. Anraku and J. Morita: Rep. Nankai Reg. Fish. Res. Lab., 22, 35-70 (1965).

23) M. UdA: This Bull., 23, 368-372 (1957). 